\title{
IMPACT ASSESSMENT OF SEWAGE TREATMENT PLANTS' EFFLUENT DISCHARGE ON THE QUALITY OF GANGA RIVER AT HARIDWAR, UTTARAKHAND
}

\author{
Rakesh Bhutiani $^{1}$, D.R. Khanna ${ }^{1}$, Ravi Kumar ${ }^{1}$, Khushi Ram ${ }^{1}$ and Faheem Ahamad ${ }^{2 *}$ \\ ${ }^{1}$ Limnology and Ecological Modelling Lab. Department of Zoology and Environmental Science, Gurukul \\ Kangri Vishwavidyalaya, Haridwar-249404 (UK), India \\ ${ }^{2}$ Keral Verma Subharti College of Sciences, (KVSCOS), Swami Vivekanand Subharti University, Meerut- \\ 250005, (UP) India
}

Corresponding Author E-mailid: rbhutiani@gmail.com

Received: 13.10.2019; Revised: 11.11.2019; Accepted: 12.12.2019

(C)Society for Himalayan Action Research and Development

\begin{abstract}
Quality of river water is of utmost important as it directly affects the life of living organism including human beings. Due to increased urbanisation and industrialisation, the generation of wastewater is increased. About half of the wastewater is continuously released in partially treated or in untreated form in the fresh water bodies. Keeping this in mind the present study was undertaken to study the impacts of STP effluent on the Ganga river in Haridwar city. The wastewater and Ganga water samples were collected and analysed for temperature, $\mathrm{pH}$, total solids (TS), total dissolved solids (TDS), total suspended solids (TSS), DO, BOD, COD and alkalinity estimation. All the parameters of wastewater and Ganga river water was found below the standard limits except the solid concentration (TS greater than 1300mg/l and TDS greater than $900 \mathrm{mg} / \mathrm{l}$ ). Due to excess amounts of total solids and very low amount of dissolved oxygen, the quality of Ganga river water after confluence zone was slightly disturbed.
\end{abstract}

Keywords: EIA, STP, Effluent, Ganga River, Haridwar

\section{Introduction}

We live on a planet that is dominated by water. Water is one of the most vital components for the survival of any kind of living organism. More than $70 \%$ of the earth's surface is covered with water. Water is the major constituent of almost all life forms. Most animals and plants contain more than $60 \%$ water by volume. Without water life would probably never have developed on our planet. In many developed countries, water pollution is a major problem and many rivers have been found to show high organic matter concentration (Anonymous, 1995). Polluted water loses its economic and aesthetic value. Water is said to be polluted when it is changed in its quality or composition directly or indirectly as a result of waste disposal and other human activities so that it becomes less suitable or harmful for drinking, domestic, agriculture, recreational, fisheries or other purposes. Therefore, monitoring the quality of water is an important task. Rivers are of immense importance geologically, biologically, historically and culturally. Although they contain only about $0.0001 \%$ of the total amount of water in the world at any given time, rivers are vital carriers of water and nutrients to areas all around the earth (Bhutiani et.al., 2017). They provide habitat, nourishment and means of transportation to countless organisms; their powerful forces create majestic scenery; they provide travel routes for exploration, commerce and recreation; they leave valuable deposits of sediments, such as sand and gravel; they form vast floodplains where many of our cities are built; and their power provides much of the electrical energy we use in 
our everyday life (Bhutiani et.al., 2018; Ruhela et.al., 2019) River pollution in India has now reached to a point of crises due to unplanned urbanization and rapid growth of industrialization (Bhutiani et.al., 2016 a and Ruhela et.al., 2018). The entire array of life in water is affected due to pollution in water. The problem of water quality deterioration is mainly due to human activities such as disposal of dead bodies, discharge of industrial and sewage wastes and agricultural runoff which are major cause of ecological damage and pose serious health hazards (Bhutiani et.al., 2016 ). Sewage disposal is a major problem in most of the cities in India. In most of the cases, the untreated sewage directly dumped into the nearest water bodies Ganga is considered as sacred and one of the major rivers of India. On the basis of basin, Ganga is ranked $1^{\text {st }}$ in India, $15^{\text {th }}$ in the Asia and $29^{\text {th }}$ in the world, draining as much as 861404 sq. km within the country, covering more than a quarter $(26.2 \%)$ of India's geographical area. The basin has large surface water and ground water resources. The annual flow in the basin is 468.7 billion cubic meters, which accounts for $25.2 \%$ of India's total water resources. Out of these only 142.6 billion cubic meters is consumed in the basin. Irrigation alone accounts for more than $94 \%$ of total basin consumption, whereas domestic and industrial sector use only 2.9 and 2.8 percent respectively. Due to much higher intensity of rainfall in the Himalayan region, the streams which join the Ganga from North contribute more than $60 \%$ of the water flowing in the Ganga basin. Over the years, water pollution has emerged as an important issue in India as most of the rivers are polluted, which are having substantial negative impact on human health and aquatic life. Controlling water pollution is urgent for ecological sustainability of water resources as well as for underlying economic reasons and human health. Therefore continuous monitoring of river bodies is essential. Keeping this in mind the present study has been taken to study the impact of treated and untreated effluent on the physicochemical properties of Ganga river in the outer stretch of Haridwar.

\section{Materials and Methods}

\section{Study area}

The present study was carried out at different sampling sites of Ganga River in outer stretch of Haridwar. Two central sewage treatment plant (STP) for the treatment of domestic waste of the city is located in the Jagjeetpur village of Haridwar (27MLD and 18MLD). The treated, untreated and partially treated water was discharged in the Ganga river via a canal that get mixed in the Ganga river near Misharpur village. The description of all the sites was presented in the Table 1 and Fig 1.

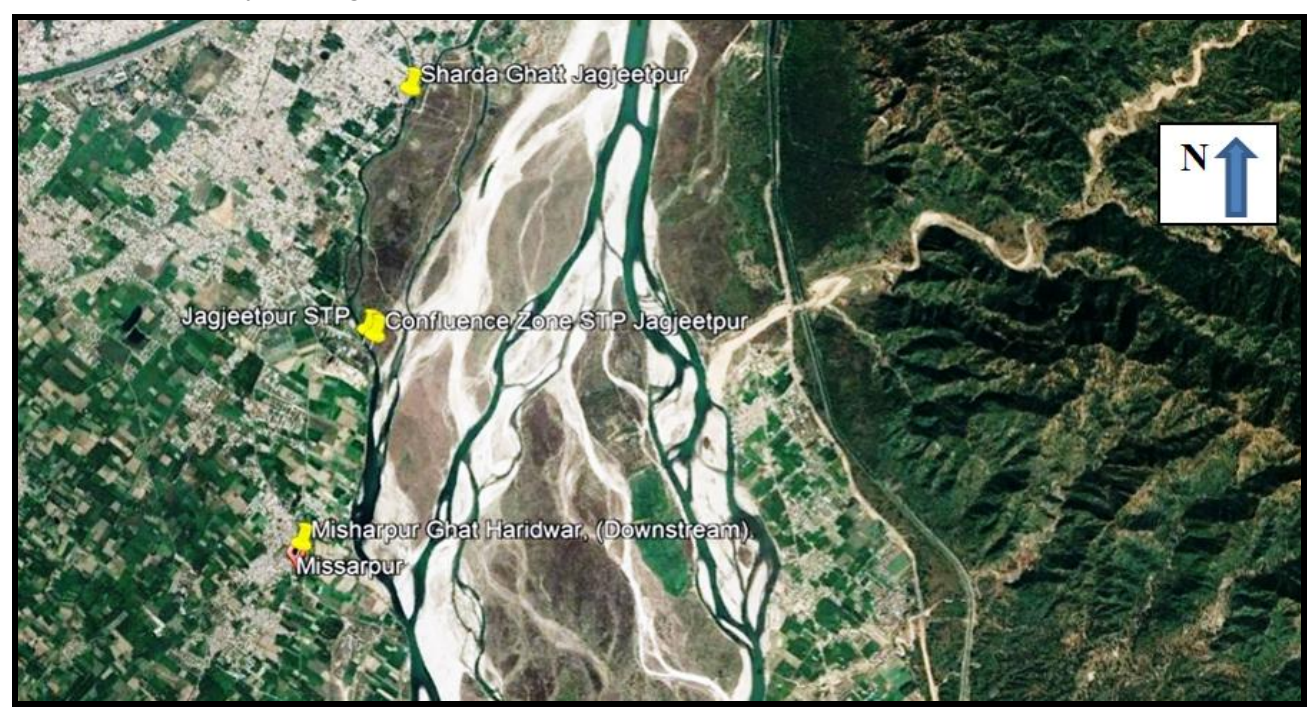

Fig. 1 Showing all the study sites (Google earth image) 


\section{Sampling and analysis}

The present study was carried out for three months from February 2017 to April 2017.Sampling frequency was fixed quarterly (Four times in a month).Sampling was performed in the morning hours from $7 \mathrm{AM}$ to 10AM. After sampling, samples were transported to the laboratory immediately and analyzed as per the standard methodology (APHA, 1995, Khanna and Bhutiani ,2008, Trivedi and Goel, 1986) The water samples from different sites of Ganga River and the STP discharge were collected in clean plastic bottles. Bottles were rinsed thoroughly 5 to 6 times with the distilled water before filling the water samples. For the collection of Dissolved oxygen and Biochemical oxygen demand BOD bottles were used.

\section{Results and Discussion}

River water quality analysis is usually required for stabilizing baseline conditions, testing quality and certain standards (Rizvi et.al., 2015)..The physicochemical characteristics that were considered in the study were water temperature, $\mathrm{pH}$, total solids (TS), total dissolved solids (TDS), total suspended solids (TSS),DO, BOD, COD and alkalinity. For the presentation in this paper result of all the studied parameters of the four sampling spots was averaged and monthly result is compiled in Table 1, while average of all the three months to show the site wise variation is given in Tables 2 .

Table 1. Showing the description of all the four sites.

\begin{tabular}{|c|c|c|c|}
\hline SN & Site name & Co-ordinates & Activities \\
\hline 1 & $\begin{array}{l}\text { Ganga river } \\
\text { ShardaGhattJagjeetpur, } \\
\text { Haridwar } \\
\text { Upstream (Fig-1) }\end{array}$ & $\begin{array}{l}\text { Latitude- } 29^{\circ} 55^{\prime} 6.18 " \mathrm{~N} \\
\text { Longitude- } 78^{\circ} 88^{\prime} 38.00^{\prime \prime} \mathrm{E}\end{array}$ & $\begin{array}{l}\text { Near the Kankhal area } \\
\text { Used for bathing purpose and it is } \\
\text { also used as recreational spot }\end{array}$ \\
\hline 2 & $\begin{array}{l}\text { Discharge of STP Plant, } \\
\text { Jagjeetpur, Source of } \\
\text { wastewater (Fig-2) }\end{array}$ & $\begin{array}{l}\text { Latitude- } 29^{\circ} 54^{\prime} 3.05 " \mathrm{~N} \\
\text { Longitude- } 78^{\circ} 8^{\prime} 25.58^{\prime \prime} \mathrm{E}\end{array}$ & $\begin{array}{l}27 \text { MLD and } 18 \text { MLD STP } \\
\text { For the treatment of domestic } \\
\text { wastewater generated from Haridwar } \\
\text { city }\end{array}$ \\
\hline 3 & $\begin{array}{l}\text { Confluence Zone (Ganga river } \\
\text { near Sewage Treatment Plant, } \\
\text { Jagjeetpur) Haridwar(Fig-3) }\end{array}$ & $\begin{array}{l}\text { Latitude- } 29^{\circ} 54^{\prime} 1.74 " \mathrm{~N} \\
\text { Longitude- } 78^{\circ} 8^{\prime} 27.66^{\prime \prime} \mathrm{E}\end{array}$ & $\begin{array}{l}\text { Site where the effluents (treated and } \\
\text { untreated) form STO get mixed in } \\
\text { the Ganga river }\end{array}$ \\
\hline 4 & $\begin{array}{l}\text { Ganga River near Misharpur, } \\
\text { MisharpurGhatHaridwar } \\
\text { Downstream (Fig-4) }\end{array}$ & $\begin{array}{l}\text { Latitude- } 29^{\circ} 53^{\prime} 7.26^{\prime \prime} \mathrm{N} \\
\text { Longitude- } 78^{\circ} 8^{\prime} 6.23^{\prime \prime E}\end{array}$ & $\begin{array}{l}\text { This is the site is located near village } \\
\text { Misharpur known as } \\
\text { MisharpurGhatt, about } 300 \text { Meters } \\
\text { down from the STP discharge. }\end{array}$ \\
\hline
\end{tabular}

Temperature plays an important role in aquatic ecosystem. Change in temperature was observed in water due to biotic and abiotic reaction and due to change in atmosphere (Rangrajan and Sarin, 2004). In fact, no other single factor has any instant and direct and indirect effect on the biota of an ecosystem as it influences the chemical, physical and bio-chemical characteristics of water body. In the present study the minimum temperature of water was observed $16.5^{\circ} \mathrm{C} \pm 0.6$ at sampling site $\mathrm{I}$ in the month of February and maximum was observed $20.6^{\circ} \mathrm{C} \pm 0.52$ at sampling site III in the month of April. 
Table 2: Monthly average values of Physico chemical parameters

\begin{tabular}{|c|c|c|c|c|c|c|c|c|c|c|c|c|}
\hline \multirow{2}{*}{$\begin{array}{l}\text { Parameters } \\
\text { /Month }\end{array}$} & \multicolumn{4}{|c|}{ FEBRUARY } & \multicolumn{4}{|c|}{ MARCH } & \multicolumn{4}{|c|}{ APRIL } \\
\hline & $\begin{array}{c}\text { SITE } \\
\text { I }\end{array}$ & $\begin{array}{c}\text { SITE } \\
\text { II }\end{array}$ & SITE III & SITE IV & $\begin{array}{c}\text { SITE } \\
\text { I }\end{array}$ & $\begin{array}{c}\text { SITE } \\
\text { II }\end{array}$ & SITE III & SITE IV & $\begin{array}{c}\text { SITE } \\
\text { I }\end{array}$ & $\begin{array}{c}\text { SITE } \\
\text { II }\end{array}$ & SITE III & SITE IV \\
\hline $\begin{array}{c}\text { Temp. } \\
\left({ }^{\circ} \mathrm{C}\right)\end{array}$ & $\begin{array}{l}16.5 \\
\pm 0.6\end{array}$ & $\begin{array}{c}19.3 \\
\pm 0.09\end{array}$ & $\begin{array}{c}18.7 \\
\pm 0.01\end{array}$ & $\begin{array}{c}17.8 \\
\pm 0.28\end{array}$ & $\begin{array}{c}17.5 \\
\pm 0.67\end{array}$ & $\begin{array}{c}20.1 \\
\pm 0.11\end{array}$ & $\begin{array}{c}19.2 \\
\pm 0.08\end{array}$ & $\begin{array}{c}18.9 \\
\pm 0.07\end{array}$ & $\begin{array}{c}18.6 \\
\pm 0.57\end{array}$ & $\begin{array}{c}20.6 \\
\pm 0.52\end{array}$ & $\begin{array}{c}20.1 \\
\pm 0.08\end{array}$ & $\begin{array}{c}20.3 \\
\pm 0.99\end{array}$ \\
\hline $\begin{array}{c}\text { TSS } \\
(\mathrm{mg} / \mathrm{l})\end{array}$ & $\begin{array}{c}445 \\
\pm 21.2\end{array}$ & $\begin{array}{c}450.5 \\
\pm 7.7\end{array}$ & $\begin{array}{l}463.5 \\
\pm 2.12\end{array}$ & $\begin{array}{c}460 \\
\pm 28.2\end{array}$ & $\begin{array}{l}360.5 \\
\pm 34.6\end{array}$ & $\begin{array}{c}451 \\
\pm 1.4\end{array}$ & $\begin{array}{c}461 \\
\pm 1.41\end{array}$ & $\begin{array}{l}370.5 \\
\pm 34.6\end{array}$ & $\begin{array}{c}347 \\
\pm 1.4\end{array}$ & $\begin{array}{c}454 \\
\pm 11.3\end{array}$ & $\begin{array}{l}464.5 \\
\pm 2.12\end{array}$ & $\begin{array}{l}370.5 \\
\pm 34.6\end{array}$ \\
\hline $\begin{array}{c}\text { TDS } \\
(\mathrm{mg} / \mathrm{l}) \\
\end{array}$ & \begin{tabular}{|c|}
750 \\
\pm 70.7 \\
\end{tabular} & $\begin{array}{c}945 \\
\pm 21.2 \\
\end{array}$ & $\begin{array}{c}875 \\
\pm 35.3 \\
\end{array}$ & \begin{tabular}{|c|}
895 \\
\pm 63.6 \\
\end{tabular} & $\begin{array}{c}400 \\
\pm 353.3 \\
\end{array}$ & $\begin{array}{c}920 \\
\pm 42.4 \\
\end{array}$ & $\begin{array}{l}1006.5 \\
\pm 79.9 \\
\end{array}$ & \begin{tabular}{|c|}
795 \\
\pm 7.07 \\
\end{tabular} & $\begin{array}{c}740 \\
\pm 70.7 \\
\end{array}$ & \begin{tabular}{|l|}
907.5 \\
\pm 17.6 \\
\end{tabular} & \begin{tabular}{|l|}
977.5 \\
\pm 24.7 \\
\end{tabular} & $\begin{array}{c}795 \\
\pm 26.8 \\
\end{array}$ \\
\hline $\begin{array}{c}\mathrm{TS} \\
(\mathrm{mg} / \mathrm{l})\end{array}$ & $\begin{array}{r}1195 \\
\pm 91.9\end{array}$ & $\begin{array}{l}1395.5 \\
\pm 28.9\end{array}$ & $\begin{array}{l}1338.5 \\
\pm 37.4\end{array}$ & $\begin{array}{r}1355 \\
\pm 91.9\end{array}$ & $\begin{array}{r}1060.5 \\
\pm 105.3\end{array}$ & $\begin{array}{c}1371 \\
\pm 43.8\end{array}$ & $\begin{array}{l}1467.5 \\
\pm 78.5\end{array}$ & $\begin{array}{r}1165 \\
\pm 41.7\end{array}$ & $\begin{array}{r}1128 \\
\pm 11.3\end{array}$ & $\begin{array}{r}1306 \\
\pm 72.1 \\
\end{array}$ & $\begin{array}{c}1334 \\
\pm 125.8\end{array}$ & $\begin{array}{l}1165.5 \\
\pm 23.3\end{array}$ \\
\hline $\mathrm{pH}$ & $\begin{array}{c}7.9 \\
\pm 0.02 \\
\end{array}$ & $\begin{array}{c}7.58 \\
\pm 0.02\end{array}$ & $\begin{array}{c}7.92 \\
\pm 0.04\end{array}$ & $\begin{array}{c}7.86 \\
\pm 0.11 \\
\end{array}$ & $\begin{array}{c}7.89 \\
\pm 0.06\end{array}$ & $\begin{array}{c}7.5 \\
\pm 0.01 \\
\end{array}$ & $\begin{array}{c}7.9 \\
\pm 0.03\end{array}$ & $\begin{array}{c}7.84 \\
\pm 0.03\end{array}$ & $\begin{array}{c}7.85 \\
\pm 0.04\end{array}$ & $\begin{array}{c}7.5 \\
\pm 0.01 \\
\end{array}$ & $\begin{array}{c}7.7 \\
\pm 0.23\end{array}$ & $\begin{array}{c}7.84 \\
\pm 0.02\end{array}$ \\
\hline $\begin{array}{c}\mathrm{DO} \\
(\mathrm{mg} / \mathrm{l})\end{array}$ & $\begin{array}{c}7.4 \\
\pm 0.07\end{array}$ & $\begin{array}{c}2.33 \\
\pm 0.04\end{array}$ & $\begin{array}{c}3.61 \\
\pm 0.01\end{array}$ & $\begin{array}{c}3.56 \\
\pm 0.06\end{array}$ & $\begin{array}{c}7.47 \\
\pm 0.02\end{array}$ & $\begin{array}{c}2.34 \\
\pm 0.03\end{array}$ & $\begin{array}{c}3.4 \\
\pm 0.23\end{array}$ & $\begin{array}{c}3.2 \\
\pm 0.07\end{array}$ & $\begin{array}{c}7.44 \\
\pm 0.06\end{array}$ & $\begin{array}{c}2.2 \\
\pm 0.04\end{array}$ & $\begin{array}{c}3.2 \\
\pm 0.04\end{array}$ & $\begin{array}{c}3.2 \\
\pm 0.01\end{array}$ \\
\hline $\begin{array}{l}\text { BOD } \\
(\mathrm{mg} / \mathrm{l})\end{array}$ & $\begin{array}{c}2.4 \\
\pm 0.06 \\
\end{array}$ & $\begin{array}{c}5.38 \\
\pm 0.04 \\
\end{array}$ & $\begin{array}{c}6.22 \\
\pm 0.04 \\
\end{array}$ & $\begin{array}{c}5.25 \\
\pm 0.07 \\
\end{array}$ & $\begin{array}{c}2.05 \\
\pm 0.42 \\
\end{array}$ & $\begin{array}{c}5.4 \\
\pm 0.01 \\
\end{array}$ & $\begin{array}{c}6.2 \\
\pm 0.01 \\
\end{array}$ & $\begin{array}{c}6 \\
\pm 0.54 \\
\end{array}$ & $\begin{array}{c}2.19 \\
\pm 0.65 \\
\end{array}$ & $\begin{array}{c}5.5 \\
\pm 0.07 \\
\end{array}$ & $\begin{array}{c}6.2 \\
\pm 0.01 \\
\end{array}$ & $\begin{array}{c}6 \\
\pm 0.13 \\
\end{array}$ \\
\hline $\begin{array}{l}\text { COD } \\
(\mathrm{mg} / \mathrm{l}) \\
\end{array}$ & $\begin{array}{c}8.3 \\
\pm 0.05 \\
\end{array}$ & $\begin{array}{c}19.2 \\
\pm 0.03 \\
\end{array}$ & $\begin{array}{c}20.2 \\
\pm 0.06 \\
\end{array}$ & $\begin{array}{c}18.7 \\
\pm 0.69 \\
\end{array}$ & $\begin{array}{c}6.5 \\
\pm 2.4 \\
\end{array}$ & $\begin{array}{c}20.1 \\
\pm 0.03 \\
\end{array}$ & $\begin{array}{c}22.2 \\
\pm 0.72 \\
\end{array}$ & $\begin{array}{c}21.1 \\
\pm 1.41 \\
\end{array}$ & $\begin{array}{c}5.5 \\
\pm 1.0 \\
\end{array}$ & $\begin{array}{c}21.1 \\
\pm 1.41 \\
\end{array}$ & $\begin{array}{c}22.7 \\
\pm 0.66 \\
\end{array}$ & $\begin{array}{r}21.15 \\
\pm 1.44 \\
\end{array}$ \\
\hline $\begin{array}{c}\text { Alkalinity } \\
(\mathrm{mg} / \mathrm{l})\end{array}$ & $\begin{array}{c}75.5 \\
\pm 0.71 \\
\end{array}$ & $\begin{array}{r}73.5 \\
\pm 2.12 \\
\end{array}$ & $\begin{array}{c}78.5 \\
\pm 0.71\end{array}$ & $\begin{array}{c}79 \\
\pm 1.41\end{array}$ & $\begin{array}{c}76 \\
+5.66\end{array}$ & $\begin{array}{c}77 \\
\pm 1.41 \\
\end{array}$ & $\begin{array}{c}77 \\
\pm 1.41\end{array}$ & $\begin{array}{c}79 \\
\pm 4.24\end{array}$ & $\begin{array}{l}79.5 \\
\pm 7.7\end{array}$ & $\begin{array}{c}78 \\
\pm 2.8\end{array}$ & $\begin{array}{l}74.2 \\
\pm 1.7\end{array}$ & $\begin{array}{c}79 \\
\pm 1.41\end{array}$ \\
\hline
\end{tabular}

A total solid is the term applied to the material residue left in the vessel after evaporation of the sample and its subsequent drying in an oven at a temperature of $103^{\circ} \mathrm{C}-105^{\circ} \mathrm{C}$.In the present investigation it was noted that the minimum value of total solids was recorded $1060.5 \mathrm{mg} / \mathrm{l} \pm 105.3$ at the site I in the month of March and the maximum $1467.5 \mathrm{mg} / 1 \pm 79.9$ at the sampling site III in the month of March. Total solids causes ecological imbalance in the aquatic ecosystem by technical abrasive action. Same trend were also reported by (Mallika et.al. 2017, Mahananda et.al. 2017). The basic principle involved is gravimetric. A wellmixed sample is filtered through standard glass fiber filter and known quantity of the filtrate is evaporated to dryness in an oven at $103-105^{\circ} \mathrm{C}$. The increase in weight represents the Total Dissolved Solids. The term 'residue' denotes the material remaining in the dish after evaporation of water sample and drying in an oven at a definite temperature.Total dissolved solids indicate the salinity behavior of water. The total dissolved solids value ranges from minimum $400 \mathrm{mg} / 1 \pm 353.3$ at the sampling site I in the month of March and maximum $1006.5 \mathrm{mg} / 1 \pm 79.9$ at the sampling site III in the month of March. - Khanna et.al. (2007) observed similar trend of variation.
Suspended solids are the portions of solids that are retained on a filter of standard specified size (generally $2.0 \mu$ ) under specific conditions. Water with high-suspended solids is unsatisfactory for bathing, industrial and other purposes. Total suspended solids are the measure of the matter present in suspended form which may be organic or may be inorganic. Color in the water is also caused by the total suspended solids. Total suspended solids can be measured by subtracting the value of total dissolved solids from the value of total solids. The value of the total suspended solids was found minimum at the sampling site I in the month of April $(347 \mathrm{mg} / \mathrm{l} \pm 1.41)$ and the maximum $464.5 \mathrm{mg} / \mathrm{l} \pm 2.12$ at the sampling site III in the month of April. A more or less similar trend was observed by Agarwal and Govind (20190). The $\mathrm{pH}$ of healthy rivers is usually around neutral or ranging between 6.5 to 8.5.It affects the dissolved oxygen level in the water, photosynthesis of aquatic plants and metabolic rates of the organisms. The maximum fluctuation in the $\mathrm{pH}$ value found to be $7.5 \pm 0.01$ at the site II in March and the maximum $7.92 \pm 0.04$ at the sampling site III in the month of February.A more or less similar trend was observed by Ashu and Kumar (2010) and Bawa et.al. (2013). 
A sufficient level of oxygen must be present in any aquatic ecosystem to support life and facilitate the natural behavior of the species. Oxygen exists in water in a dissolved stage at a level equal to its saturation concentration, which is mostly dependent on temperature.Dissolved oxygen is one of the most important parameter in water quality assessment. Its presence is essential to maintain variety of forms of life in the water and the effect of waste discharge in a water body is largely determined by the oxygen balance of the system. The DO value indicates the degree of pollution in the water bodies. It was found minimum ranges $2.3 \mathrm{mg} / \mathrm{l} \pm 0.4$ at the sampling site II in the month of February and the maximum $7.4 \mathrm{mg} / \mathrm{l} \pm 0.02$ at the sampling site $\mathrm{I}$ in the month of March. Same trend was also reported by Khanna and Bhutiani (2003). The BOD is the amount of oxygen required by bacteria for stabilizing decomposable organic matter under aerobic conditions. The decomposition of organic impurities in presence of bacteria results in utilization of a part of the dissolved oxygen by the bacteria during their respiratory and metabolic activities. BOD determination is still the best available single test for assessing organic pollution. It represents the amount of oxygen that microbes need to stabilize biologically oxidizable matter. In the present study the value of BOD ranged from $2.4 \mathrm{mg} / \mathrm{l} \pm 0.06$ at the sampling site I in the month of February to $6.2 \mathrm{mg} / \mathrm{l} \pm 0.04$ at the sampling site III in the month of the February. Same trend was also reported by Trivedi et.al. (2009) and Bhutiani et.al. (2011). Chemical oxygen demand determination provides a measurement of oxygen equivalent of the portion of organic matter in a sample that is sub scriptable to oxidation by a strong oxidant. It is commonly used to measure the amount of organic compounds in the water indirectly. The minimum COD was found at the sampling site $\mathrm{I}$ in the month of March $(6.5 \mathrm{mg} / \mathrm{l} \pm 2.4)$ and the maximum at the sampling site III in the month of March $(22.2 \mathrm{mg} / \mathrm{l} \pm 0.72)$. Same trend was also reported by Haritash et.al. (2014).

Table 3. Showing average values of all the physico-chemical parameters

\begin{tabular}{|l|l|l|l|l|}
\hline Parameter/Site & Site-1 & Site-2 & Site-3 & Site-4 \\
\hline Temp. & $17.5 \pm 1.1$ & $20 \pm 0.66$ & $19.2 \pm 0.9$ & $19.3 \pm 1.25$ \\
\hline TSS $(\mathrm{mg} / \mathrm{l})$ & $384.2 \pm 53.11$ & $451.8 \pm 1.89$ & $463.0 \pm 1.80$ & $400.3 \pm 51.67$ \\
\hline $\mathrm{TDS}(\mathrm{mg} / \mathrm{l})$ & $630.0 \pm 199.25$ & $924.2 \pm 19.09$ & $953.0 \pm 69.09$ & $828.3 \pm 57.74$ \\
\hline $\mathrm{TS}(\mathrm{mg} / \mathrm{l})$ & $1127.8 \pm 67.25$ & $1357.5 \pm 46.25$ & $1380.0 \pm 75.81$ & $1228.5 \pm 109.55$ \\
\hline $\mathrm{pH}$ & $7.9 \pm 0.04$ & $7.5 \pm 0.04$ & $7.9 \pm 0.08$ & $7.8 \pm 0.01$ \\
\hline $\mathrm{DO}(\mathrm{mg} / \mathrm{l})$ & $7.5 \pm 0.02$ & $2.3 \pm 0.03$ & $3.4 \pm 0.17$ & $3.3 \pm 0.21$ \\
\hline BOD $(\mathrm{mg} / \mathrm{l})$ & $2.4 \pm 0.20$ & $5.5 \pm 0.09$ & $6.2 \pm 0.03$ & $5.8 \pm 0.43$ \\
\hline $\mathrm{COD}(\mathrm{mg} / \mathrm{l})$ & $8.3 \pm 1.42$ & $20.2 \pm 0.94$ & $21.7 \pm 1.33$ & $20.3 \pm 1.41$ \\
\hline Alkalinity(mg/l) & $75.5 \pm 2.18$ & $76.2 \pm 2.36$ & $76.6 \pm 2.18$ & $79.0 \pm 0.00$ \\
\hline
\end{tabular}

The total alkalinity of water is generally imparted by the salts of carbonates, bi carbonates, phosphate and nitrates etc. and together with hydroxyl ions in the Free State. Alkalinity increases due to decomposition of organic matter that has settled at the bottom. Total alkalinity in water is due to salts of weak acids and bicarbonates of highly alkaline water.
The minimum alkalinity value was found at the sampling site III in the month of March $(74.2 \mathrm{mg} / \mathrm{l} \pm 1.7)$ and the maximum $(79.5 \mathrm{mg} / \mathrm{l} \pm 7.7)$ at the sampling site I in the month of April. Same trend is also observed by Khanna and singh (1999). 


\section{Conclusion}

The findings of the present study showed that water discharged from the treatment plant was not properly treated sometimes and partially treated water was continuously and directly discharged into the Ganga river. The amount of total solids of the discharged effluent affects the Ganga river by reducing the transparency due to increase of the solids in the river water, thereby reducing the photosynthetic activity and as a results the dissolved oxygen content also decreased, which affects the living organism of the Ganga river. Due to discharge of the effluent, having high BOD, the dissolved oxygen of the Ganga decreased to a considerable extent affecting the different reactions occurring inside the river and as a result change in the water quality of the river. Dead bodies burning activities was also observed at the downstream of the river, which further deteriorate the water quality of Ganga river.

\section{References}

Agarwal KA and Govind SR (2010). Physico chemical and Microbiological study of Tehri Dam Reservoir, Garhwal Himalaya, India.Journal of American Science6(6):65-71.

Ashu and Kumar M (2010). Monitoring of Ganga water at Shukratal of Muzaffarnagar District (U.P), India, Biohelica., 1(2): 49-52.

Bawa, Kalpana V and Gaikawad VB (2013). Water Quality Assessment of Godavari River at Nashik, India: Impact of Sewage and Industrial Wastewater. Universal Journal of Environmental Research and Technology, 3(4): 452-457.

Bhutiani R, Ahamad F, Tyagi V and Ram K (2018). Evaluation of water quality of River Malin using water quality index (WQI) at Najibabad, Bijnor (UP) India. Environ. Cons. Jour., 19 (1\&2): 191-201.

Bhutiani R, Khanna DR, Shubham and Ahamad F (2016b). Physico-chemical analysis of Sewage water treatment plant at Jagjeetpur, Haridwar, Uttarakhand. Environ. Cons. Jour., 17(3): 133-142.
Bhutiani R, Ruhela M and Ahamad F (2017). Limnological Characterization of Hindon River at NCR (Uttar Pradesh) India. Environ. Cons. Jour., 18(1\&2): 219-229.

Bhutiani, R, Khanna, D.R. and Kulkarni, D.B.(2011). Study on pollution status: impact on water quality of river Ganga at Haridwar. Environment conservation journal, 12(1-2):915.

Bhutiani, R., Khanna, D.R., Khushi R, Ahamad F and Tyagi V (2016a). Quality Assessment of Ganga River at Haridwar With Reference To Various Physico-Chemical Parameters. Biotechnology International, 9(1): 17-24.

Haritash AK, Gaur S and Garg S (2014). Assessment of water quality and suitability analysis of RiverGanga in Rishikesh, India. Appl Water Sci., 13201-014-0235-1

Khanna D R and Bhutiani R. (2008). Laboratory manual of water and Waste water Analysis. Daya Publishing House New Delhi -110002.

Khanna DR and Singh S (1999). Diurnal variation in microbial ecology of Narkewala Pond at Ferupur, Hardwar, Sus. Eco. Sys. andEnv. , Ed. By D.R Khanna, A.Gautam and A.Gautam pp-99-104.

Khanna DR, Singh V, Bhutiani R, Chandra KS, Matta G and Kumar D (2007). A study of biotic and abiotic factors of Song River at Dehradun. Environment Conservation Journal, 8 (3): 117-126.

Khanna, D.R. and Bhutiani, R. (2003). Limnological characteristics of the River Ganga at Hardwar (Uttaranchal). U.P. Jour. Zool.,23(3):179-183.

Mahananda, Mohanty BP and Behera NR (2010). Physico chemical analysis of surface and ground water of Bargarh District, Orissa, India. IJR RAS2 (3).

Mallika S, Umamaheswari R and Krishnamoorthy S (2017). Physico-Chemical parameters and bacteriological study of vaigai River Water Madurai district, Tamilnadu, India. Int. Jr. of Fisheries and Aquatic Studies (IJFAS). 5(1): 42-45.

Rengarajan R and Sarin MM (2004). Distribution of rare earth element in the Yamuna and the 
Chambal rivers, India, Geochemical Journal,30: 551-569.

repeatedAPHA (1995). Standard methods for examination of water and waste water. American Public Health Association, Inc, New York. $15^{\text {th }}$ edition.

Rizvi N, Katyali D and Joshi V (2015). Assessement of water quality of Hindon River in Ghaziabad and Noida, India by using multivariate statistical analysis. Jr.of Global Ecology and Env.(JOGEE)3(2): 80-90.

Ruhela M, Bhutiani R, Ahamad F and Khanna DR (2019). Impact of Hindon River Water on Selected Riparian Flora (AzadirachtaIndica and Acacia Nilotica) with special Reference to Heavy Metals. Pollution, 5(4): 749760.DOI: $10.22059 /$ poll.2019.275662.583

Ruhela M, Kumar P, Tyagi V, Ahamad F and Ram K (2018). Assessment of water quality of River Ganga at Haridwar with reference to Water Quality Index. Environ. Cons. Jour., 19 (3):47-58.

Trivedi P, Bajpai A and Thareja S (2009). Evaluation of water quality; Physico chemical characterstics of river Ganga at Kanpur City. Nature and Scince, 1(6): 91-94.

Trivedy PK and Goel PK (1986). Chemical and Biological methods for water pollution studies. Environment Publication, Karad.

UNEP/GEMS (1995). Monitored the water quality of different rivers in the India, China, Brazil. Tripathy and Adhikari., (1990). UttarkashiGarhwal, Preliminary studies on the water pollution of river Nandira. Indian Jour. Env.Hlth 32(4).

$* * * * * * * * *$ 